\title{
Handling of children by diversion in children protection (Diversion and Restorative
}

\author{
Justice) \\ Tratamento de crianças por meio de desvio na proteção infantill (Desvio e Justiça Restaurativa) \\ Manejo de niños por desvío en protección infantil (Desvío y Justicia Restaurativa)
}

Received: 01/09/2021 | Reviewed: 01/09/2021 | Accept: 01/10/2021 | Published: 01/13/2021

Tito Eliandi

ORCID: https://orcid.org/0000-0003-3042-8588 Faculty of Law, Universitas 17 Agustus 1945 Surabaya, Indonesia E-mail: tito.eliandi@gmail.com

Teguh Prasetyo

ORCID: https://orcid.org/0000-0002-6393-6442 Faculty of Law, Universitas 17 Agustus 1945 Surabaya, Indonesia E-mail: bejana1@protonmail.com

Otto Yudianto

ORCID: https://orcid.org/0000-0001-8996-0195 Faculty of Law, Universitas 17 Agustus 1945 Surabaya, Indonesia E-mail: otto@mail.com

\begin{abstract}
The best treatment for children who should be lived, with the best interests for the sustainability of human life. In handling criminal cases, the restorative justice approach provides different views and approaches to studying and dealing with a criminal act for the handling of restorative justice, that criminal acts are essentially from the viewpoint of criminal law in general, namely attacks on individuals and society as well as community relations. In restorative justice, it can also be found that the features of the formulation of justice are related to rights, judged by results. This meaning has brought a paradigm shift in understanding the concept of providing justice that is in the criminal justice system, it's said that because in the concept of the criminal justice system in general, justice is considered to have been achieved, the value of the perpetrator can be sanctioned by the state and the victim doesn't have a place in the settlement process, meanwhile. In the concept of a framework of restorative justice, perpetrators of criminal acts, victims and the whole community are involved in resolving criminal acts directly and focusing on recovery suffered by victims, while the state functions as a facilitator in the process of resolving criminal acts.
\end{abstract}

Keywords: Child protection; Diversion; Restorative justice.

\section{Resumo}

O melhor tratamento para crianças que devem ser vividas, com os melhores interesses para a sustentabilidade da vida humana. No tratamento de casos criminais, a abordagem da justiça restaurativa fornece diferentes visões e abordagens para estudar e lidar com um ato criminoso para o tratamento da justiça restaurativa, que os atos criminosos são essencialmente do ponto de vista do direito penal em geral, ou seja, ataques a indivíduos e à sociedade como bem como relações com a comunidade. Na justiça restaurativa, também se verifica que as características da formulação da justiça estão relacionadas aos direitos, julgados pelos resultados. Esse significado trouxe uma mudança de paradigma na compreensão do conceito de justiça que está no sistema de justiça criminal, diz-se que porque no conceito de sistema de justiça criminal em geral, a justiça é considerada alcançada, o valor do perpetrador pode ser sancionada pelo estado e a vítima não tem lugar no processo de liquidação, entretanto. No conceito de uma estrutura de justiça restaurativa, os perpetradores de atos criminosos, as vítimas e toda a comunidade estão envolvidos na resolução direta de atos criminosos e com foco na recuperação sofrida pelas vítimas, enquanto o Estado funciona como um facilitador no processo de resolução de atos criminosos.

Palavras-chave: Proteção à criança; Diversão; Justiça restaurativa.

\section{Resumen}

El mejor trato para los niños que deben ser vividos, con el mejor interés para la sostenibilidad de la vida humana. En el manejo de casos penales, el enfoque de justicia restaurativa proporciona diferentes puntos de vista y enfoques para estudiar y tratar un acto delictivo para el manejo de la justicia restaurativa, que los actos delictivos son esencialmente desde el punto de vista del derecho penal en general, es decir, ataques a las personas y la sociedad como así como las relaciones comunitarias. En la justicia restaurativa, también se puede encontrar que las características de la 
formulación de la justicia están relacionadas con los derechos, juzgados por los resultados. Este significado ha traído un cambio de paradigma en la comprensión del concepto de impartir justicia que se encuentra en el sistema de justicia penal, se dice que debido a que en el concepto de sistema de justicia penal en general se considera que se ha logrado la justicia, el valor del perpetrador puede ser sancionado por el estado y la víctima no tiene un lugar en el proceso de resolución, mientras tanto. En el concepto de un marco de justicia restaurativa, los autores de los hechos delictivos, las víctimas y toda la comunidad se involucran en la resolución de los hechos delictivos de manera directa y con foco en la recuperación que sufren las víctimas, mientras que el Estado funciona como facilitador en el proceso de resolución de los hechos delictivos.

Palabras clave: Protección infantil; Desviación; Justicia restaurativa.

\section{Introduction}

The paradigm shift regarding justice in criminal law is a worldwide phenomenon because the public is increasingly aware that there needs to be a radical change regarding the handling of Children with the Law. The juvenile criminal justice system which is based on retributive and restitutive justice gives full authority to law enforcers without giving the opportunity to children before the law, and their victims to deliver the version of justice they want.(Pribadi, 2018) The degree of justice is given by providing imprisonment for the perpetrator. This is one of the factors in the increasing level of crime committed by children before the law because in prison they can learn about crimes that they have never committed from other inmates.

The idea of implementing this diversion cannot be separated from the spirit of the Indonesian nation which has always prioritized deliberation and consensus in resolving every problem. For example, when a small child plays a ball and then the ball hits the glass from someone's house, the owner of the house will report the act to the child's parents, to be discussed so that an agreement can be reached either in the form of a warning or compensation. This doesn't harm both parties and maintains brotherhood between fellow humans, while the child doesn't cause trauma due to being scolded or reported to the police.

The spirit of the nation as the implementation of this diversion also comes from the moral of Pancasila which is the moral of the state.("Pendidik. Pancasila Ditinjau Dari Perspekt. Filsafat," 2018) As the moral of the state, the moral of Pancasila is the source of state order and the soul of all state activities in the field of life. Inside there are five moral principles of Pancasila, namely Divinity, Humanity, Unity, Democracy and Justice. One of the Pancasila morals that is compatible with diversion is the moral value in the fourth precept, namely deliberation.

Moral values in deliberation principles, in accordance with the values of deliberation to reach consensus, are also carried out in child protection, because in the aspect of child protection, there is recognition of children's rights regarding respect for children's opinions. In the context of diversion, respect for children's opinions needs to be considered, because the principle of diversion is to always involve the child, the wishes of the child's parents and even the victim. Without this agreement, the diversion program cannot be implemented. The value prioritizes deliberation to reach consensus and in the spirit of a family atmosphere in the context of implementing child protection, so protecting children is in accordance with the will of the protected child and does not impose the will of those who will protect the child.(Broto, 2014)

The theory of dignified justice views the importance of the implementation of diversion for children facing the law, because in essence diversion is a diversion of the process of solving children's cases from a generally accepted procedural law process to a juvenile case settlement process that uses special procedural law to resolve juvenile criminal cases. It's said that it's a special procedural law because the procedural law used to settle children's cases is special. However, even though it's special, the process cannot be separated from the general criminal justice system.

Qualification and limitation of diversion will not achieve the goal of achieving justice for children in conflict with the law. This is also contrary to the child protection law which explicitly states that against children who have problems with the law, there are special actions without distinguishing the child's criminal act or the threat of punishment imposed on the child. 
The pattern of placing children in front of the law in the Special Guidance Institution for Children must also aim to achieve restorative justice, which is intended to provide recovery for children in conflict with the law, so that children are expected to return to the social environment naturally.(Putro Ferdiawan et al., 2020) Therefore, a role is very necessary as well as all parties in order to make this happen.

The Juvenile Criminal Justice System process should aim at creating restorative justice, both for children and for victims. Restorative justice is manifested in a diversion process, in which all parties involved in a certain criminal act jointly solve problems and create an obligation to make things better by involving victims, children, and the community in finding solutions to improve, reconcile, and reassurance that isn't based on vengeance.(Hambali, 2019)

The cases of handling children that have been decided by the Court as mentioned above are an indication that the handling of children in conflict with the law hasn't shown any signs that lead to legal protection of children in conflict with the law.(Setyorini et al., 2020) There is a disparity in the Court's decisions as mentioned in above as evidence that the handling of children in conflict with the law doesn't yet have an alignment which refers to the handling of children based on justice. Justice referred to in this research is justice based on restorative justice, which is related to the dignified justice theory.(Rena Yulia, 2012)

By referring to restorative justice, what is wanted to be achieved is restoration and not punishment for crimes committed by children in conflict with the law. Recovery can only be achieved through a peaceful out-of-court settlement process. This principle is in accordance with the values of Pancasila adopted by the Indonesian people by emphasizing deliberation to reach consensus.

\section{Methodology}

This study uses document study research with a statutory approach. In this statutory approach, the laws analyzed are Law of the Republic of Indonesia Number 11 of 2012 concerning the Juvenile Criminal Justice System.(Michael, 2019)

\section{Results and Discussion}

The delinquency of children and adolescents has also recently become a cause for concern. This situation can be seen from truant behavior at school, brawls between students, free sex, drugs and others. Adolescent 'naughty' behavior can be caused by factors from the adolescent himself (internal) and factors from outside (external). Internal factors in the form of identity crisis, biological and sociological changes in adolescents allow two forms of integration. First, the formation of a feeling of consistency in his life. Second, the achievement of role identity. Juvenile delinquency occurs because adolescents fail to reach the second integration period.

It can be explained that juvenile delinquency is an act or act of violating norms, both legal norms and social norms committed by young children.(Vijayanath et al., 2010) This definition tends to be child delinquency rather than child crime, because it feels too extreme when a child commits criminal act is said to be a criminal. Child delinquency arises as a result of the natural process of every human being who must experience shocks during adulthood.(Unayah \& Sabarisman, 2015)

If the Judge seeks diversion, then within a maximum period of seven days, starting from the date the Head of the District Court determines the Judge to handle the case of the Child within a maximum period of three days, starting from the date the case is delegated from the Public Prosecutor, the Judge offers to the Child an /or parents/guardians, as well as Victims, Child Victims, and/or parents/guardians to settle the case through diversion. 


\section{The Conception of Diversion Regulation Against Children is against Justice-Based Law as an effort to Protect Children}

Whereas basically the implementation of the law that has been determined by the government must be in line with existing conditions, both in the field and outside the field, which in its activities involves several elements accompanied by efforts and supported by legal instruments.

This means that on the one hand, children who are in conflict with the law receive special protection and punishment for children in conflict with the law is the last alternative, but with the imprisonment limit of less than 7 (seven) years, it makes the desire to provide special protection for children those who are in conflict with the law become constrained.

Criminal law cannot escape from its responsive nature, as its original characteristics.(Pravitria, 2018) As a result, we can see that many problems arise as a by-product of the criminal justice system and are not problem solving. Social reactions from criminal sanctions after the occurrence of a criminal act aren't preventive in nature and even increase the desocialization of community members.

There is a correspondence between the implementation of the idea of diversion and prisonisation. The implementation of the idea of diversion is an effort to prevent children from going to prison or prisons, so this is an effort to prevent the prisoner of children. We don't close our eyes and it has been proven in several studies that the negative effects of juvenile prisons today are still real. However, if what is used as the basis is the sub-cultural elements of prison life, there will be attitudes, values and behavior of the prison community that the attitudes, values and behavior of the prison community will become more evil, just as life in prison is between a child in conflict with the law is made one with the adult criminal, so what happens is that the child will be more evil after undergoing punishment.

This settlement aims to restore the original condition of the relationship between individuals, groups, families and communities who have suffered losses due to an act that has been caused by the perpetrator of the crime. The forms of accountability provided in restorative justice are material compensation, social work, education and useful training for children.

The concept of restorative justice is a concept of justice that aims to empower victims, perpetrators, families and communities to correct an act against the law, by using awareness and conviction as a basis for improving social life.(Rochaeti, 2015)

The main principle of resolving criminal acts through a restorative approach is a solution that isn't just a tool to encourage someone to compromise the creation of an agreement, but the approach must be able to penetrate the inner space of the hearts and minds of the parties involved in the settlement process in understanding the meaning and purpose of a the restoration and sanctions that are applied are sanctions that are restorative and preventive in nature.(Marshall, 2020)

\section{Conclusion and Suggestions}

The principle of diversion for children in conflict with the law, it's found that training in handling children in conflict with the law is lacking, especially for investigators and prosecutors, even though diversion isn't only carried out at the level of examination at court. For this reason, training in handling children in conflict with the law should also be carried out in collaboration with the National Police and the Attorney General. 
Research, Society and Development, v. 10, n. 1, e26010111826, 2021

(CC BY 4.0) | ISSN 2525-3409 | DOI: http://dx.doi.org/10.33448/rsd-v10i1.11826

\section{References}

Broto, G. S. D. (2014). Riset kominfo dan UNICEF mengenai perilaku anak dan remaja dalam menggunakan internet. In Siaran Pers No. $17 /$ Pih/Kominfo/2/2014

Hambali, A. R. (2019). Penerapan Diversi Terhadap Anak Yang Berhadapan dengan Hukum Dalam Sistem Peradilan Pidana (Diversions for Children in Conflict with The Laws in The Criminal Justice System ). Jurnal Ilmu Hukum.

Marshall, C. D. (2020). Restorative justice. In Religion Matters: The Contemporary Relevance of Religion. https://doi.org/10.1007/978-981-15-2489-9_7

Michael, T. (2019). Kajian Kritis Terhadap Rancangan Peraturan Walikota Surabaya Tentang Tata Cara Penerbitan Izin Penyelenggaraan PARKIR DI LUAR RUANG MILIK JALAN. Jurnal Hukum Bisnis Bonum Commune. https://doi.org/10.30996/jhbbc.v2i1.2318

Pendidikan Pancasila ditinjau dari perspektif filsafat (aksiologi). (2018). Pendidikan Pancasila Ditinjau Dari Perspektif Filsafat (Aksiologi). https://doi.org/10.12928/citizenship.v1i1.10442

Pravitria, A. A. (2018). Anak Yang Berkonflik Dengan Hukum Yang Melakukan Pemerkosaan Terhadap Anak. Media Iuris. https://doi.org/10.20473/mi.v1i3.10158

Pribadi, D. (2018). Perlindungan Terhadap Anak Berhadapan Dengan Hukum. Jurnal Hukum Volkgeist. https://doi.org/10.35326/volkgeist.v3i1.110

Putro Ferdiawan, R. P. F., Santoso, M. B., \& Darwis, R. S. (2020). Hak Pendidikan Bagi Anak Berhadapan (Berkonflik) Dengan Hukum. Jurnal Kolaborasi Resolusi Konflik. https://doi.org/10.24198/jkrk.v2i1.27044

Rena Yulia. (2012). Keadilan Restoratif Dan Korban Pelanggaran Ham (Sebuah Telaah Awal). Jurnal Hukum Dan Peradilan.

Rochaeti, N. (2015). Implementasi Keadilan Restoratif Dan Pluralisme Hukum Dalam Sistem Peradilan Pidana Anak Di Indonesia. Masalah-Masalah Hukum. https://doi.org/10.14710/mmh.44.2.2015.150-160

Setyorini, E. H., Sumiati, S., \& Utomo, P. (2020). Konsep Keadilan Restoratif Bagi Anak Yang Berkonflik Dengan Hukum Dalam Sistem Peradilan Pidana Anak. DiH: Jurnal Ilmu Hukum. https://doi.org/10.30996/dih.v16i2.3255

Unayah, N., \& Sabarisman, M. (2015). the Phenomenon of Juvenile Delinquency and Criminality. Sosio Informa.

Vijayanath, V., Anitha, M. R., Raju, G. M., \& Babladi, P. (2010). Juvenile delinquency. Biomedical Research. https://doi.org/10.7312/ginz94534-012 